\title{
ANALISIS DESKRIPTIF PENGEMBANGAN KAWASAN EKONOMI MASYARAKAT (KEM) SIMPANG TIGA DI KOTA TANJUNG PINANG
}

\author{
Elvi Mailani $^{1 *}$, Novita Indah Hasibuan ${ }^{2}$, Yusnizar Heniwaty ${ }^{3}$ \\ ${ }^{1}$ Fakultas Ilmu Pendidikan, Universitas Negeri Medan, Medan, Indonesia \\ ${ }^{2}$ Fakultas Ekonomi, Universitas Negeri Medan, Medan, Indonesia \\ ${ }^{3}$ Fakultas Bahasa dan Seni, Universitas Negeri Medan, Medan, Indonesia \\ *Penulis Korespondensi: elvimailani@gmail.com
}

\begin{abstract}
Abstrak
Kampung Madong RT 1/ RW 5 merupkan salah satu kampung yang terletak di kelurahan Kampung Bugis, kecamatan Tanjungpinang Kota, Kota Tanjungpinang, Propinsi Kepulauan Riau. Kondisi umum wilayah adalah merupakan daerah pesisir dengan jenis tanah berlumpur. Kampung dengan jumlah penduduk 448 jiwa $(136 \mathrm{KK})$, dengan luas wilayah yang dihuni \pm 4 Ha. Jarak tempuh dari Pusat Pemerintahan Kota Tanjungpinang dengan jarak $18 \mathrm{Km}$, dengan waktu tempuh sekitar 20 menit (menggunakan kendaraan roda empat/roda dua). Jalan akses memiliki lebar ratarata 6 meter dengan perkerasan aspal. Akses untuk mencapai lokasi cukup mudah karena umumnya masyarakat disekitar memiliki kendaraan roda dua. Masyarakat juga dapat mencapai Kota Tanjung Pinang melalui wilayah laut dengan menggunakan perahu bermesin dengan waktu tempuh sekitar 10 menit. Pelaksanaan kegiatan KEM Madong terhitung mulai tanggal 29 September 2017. Strategi yang diterapkan pada KEM ini adalah pemberian bantuan kelengkapan dan bahan baku bagi masyarakat untuk meningkatkan ekonomi masyarakat. Kelengkapan dan bahan baku ini terkait dengan kegiatan harian masyarakat dalam mencari nafkah dan meningkatkan taraf hidupnya. Diharapkan keterbatasan modal masyarakat dalam menyediakan kelengkapan dan bahan baku ini dapat diatasi dengan bantuan dari Pertamina melalui program ini. Dengan adanya program ini,jumlah penerima manfaat sebanyak 51 orang yang terbagi dalam lima kelompok kecil untuk memudahkan pelaksanaan kegiatan. Sampai dengan laporan ini disampaikan \pm 8 bulan, kegiatan panen baru saja dilaksanakan. Budidaya ikan jenis kerapu cantang ini akan menuai hasilnya setelah durasi 8 bulan sejak penyebaran benih dengan rerata berat ikan sebesar 700- 800 gram/ekor.
\end{abstract}

Kata kunci: Budidaya Ikan Lele, Kawasan Ekonomi Masyarakat, Kerambah Apung, Kota Tanjung Pinang

\begin{abstract}
Madong Village is one of the villages located in the village of Bugis Village at the city of Tanjungpinang, the capital city of Riau Islands Province. The general land condition of the area is covered by coastal areas with large amount of muddy soil found in all over places in the city. The number of people in Madong village amounted of 448 people (136 families), with a total area of \pm 4 hectares. It is a shortdistance in between the Tanjungpinang City Government Center and the village (18 Km), with a travel time of about 20 minutes (using a four-wheeled vehicle / two-wheeled vehicle). The access road has an average width of 6 meters with asphalt pavement. Access to reach the location is quite easy because generally the surrounding community has two-wheeled vehicles. The community can also reach the city of Tanjung Pinang through the sea by using motorized boats with a travel time of about 10 minutes. The implementation of KEM Madong activities began on September 29, 2017. The strategy adopted in this KEM was the provision of completeness and raw materials for the community to improve the economy of the community. Completeness and raw materials are related to the daily activities of the community in earning a living and improving their standard of living. It is expected that the limited capital of the community in providing these raw materials and materials can be overcome with assistance from Pertamina through this program. With this program, there were 51 beneficiaries divided into five small groups to facilitate the implementation of activities. Until this report was delivered \pm 8 months, harvesting was just carried out. The harvesting of cantang grouper fish takes up to 8 months and expected to have a fish weight around 700-800 grams.
\end{abstract}

Keywords: Cat Fish Harvesting, Community Economic Zone, Floating Cages, Tanjung Pinang City 


\section{PENDAHULUAN}

\subsection{Letak/Posisi Wilayah KEM}

Rencana Lokasi Lahan KEM (Kawasan Ekonomi Masyarakat) Kampung Madong RT 1/ RW 5 merupkan salah satu kampung yang terletak di kelurahan Kampung Bugis, kecamatan Tanjungpinang Kota, Kota Tanjungpinang, Propinsi Kepulauan Riau. Lokasi wilayah Desa Madong sebagaimana tampak pada Gambar 1.

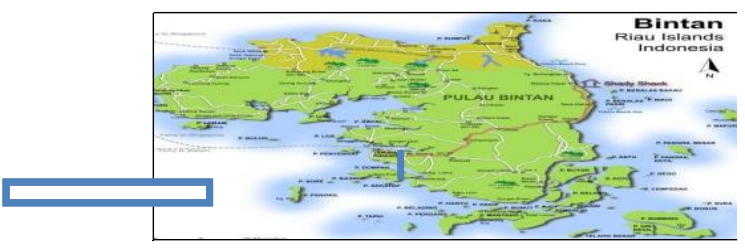

\section{Gambar 1. Lokasi Desa Madong, Pulan Bintan, Kepri}

Kondisi umum wilayah adalah merupakan daerah pesisir dengan jenis tanah berlumpur. Kampung dengan jumlah penduduk 448 jiwa (136 KK), dengan luas wilayah yang dihuni \pm 4 Ha. Jarak tempuh dari Pusat Pemerintahan Kota Tanjungpinang dengan jarak $18 \mathrm{Km}$, dengan waktu tempuh sekitar 20 menit (menggunakan kendaraan roda empat/roda dua). Jalan akses memiliki lebar rata- rata 6 meter dengan perkerasan aspal. Akses untuk mencapai lokasi cukup mudah karena umumnya masyarakat disekitar memiliki kendaraan roda dua. Masyarakat juga dapat mencapai Kota Tanjung Pinang melalui wilayah laut dengan menggunakan perahu bermesin dengan waktu tempuh sekitar 10 menit.

Secara umum masyarakat di wilayah ini bermata pencaharian sebagai nelayan, pembudidaya, pengolah hasil perikanan (kerupuk, dan minyak gamat), dan sebagian kecil sebagai buruh. Lahan yang sudah dimanfaatkan seluas $1 \mathrm{Ha}$ yang merupakan wilayah laut milik masyarakat setempat. Batas-batas wilayah Kampung Madong adalah sebagai berikut:

a) Sebelah utara berbatasan dengan Desa Tembeling

b) Sebelah timur berbatasan dengan

Kelurahan Air Raja

c) Sebelah selatan berbatasan dengan Kelurahan Tg.Pinang Kota

d) Sebelah barat berbatasan dengan

Kelurahan Senggarang

\subsection{Karakteristik Lahan}

Secara umum topografi Kampung Madong ini merupakan wilayah pesisir dengan jenis tanah berlumpur. Dimana terdiri dari $60 \%$ laut dan $40 \%$ daratan yang banyak ditumbuhi oleh hutan mangrove yang hingga sampai saat ini kelestariannya tetap terjaga dengan baik, sebagaimana pada Gambar 2. Kondisi fisik Kawasan di Kampung Madong, Kelurahan Kampung Bugis cocok untuk budidaya ikan air laut dan sangat berpotensi untuk mendapatkan hasil budidaya yang baik.

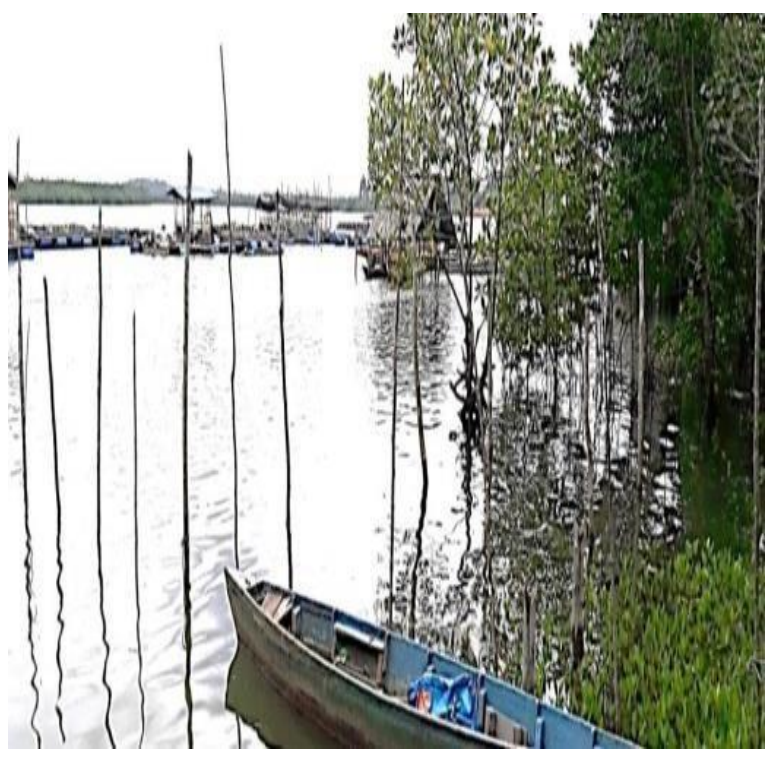

Gambar 2. Wilayah pesisir Desa Madong

\subsection{Potensi SDA}

Terdapat dua musim, yaitu musim hujan dan musim panas. Potensi SDA pada lokasi perkembangan budidaya ikan air laut sudah berjalan dengan baik dikarenakan adanya keinginan keras masyarakat di kampung ini dalam mengembangkan potensi budidaya tersebut. Wilayah ini merupakan penghasil makanan khas laut seperti gonggong, ketam, sotong, asam pedas ikan sembilang dan udang. Dengan potensi ini, masyarakat Kampung Madung membuka usaha rumah makan khas laut yang banyak dikunjungi wisatawan domestik dan luar negeri. Dalam mengembangan usaha ini, masyarakat di kampung ini juga sangat tergantung pada ketersediaan bibit, pakan ikan dan jenis serta ukuran keramba yang digunakan. Kondisi lahan awal adalah hamparan pada luasan sekitar 300 $\mathrm{m} 2$ di pinggir pantai.

\subsection{Pendidikan Masyarakat}

Disamping itu di kampong ini juga terdapat sekolah satu atap yang terdiri dari Taman Kanak Kanak Bunga Raya, SD Negeri 006 Kota, dan SMP Negeri 14 Tanjungpinang. Jumlah siswa tidak banyak, sehingga satu kelas hanya diisi oleh 11- 20 orang siswa. Tenaga pengajar hanya 4 orang saja yang berdomisili di kampong ini, sementara 15 orang lagi bertempat tinggal diluar kampong Madong.

\subsection{Kesehatan Masyarakat}

Kondisi alam yang masih dikategorikan masih alami, sangat mendukung kondisi kesehatan masyarakat setempat. Di daerah ini juga tidak ada aktifitas pabrik atau kegiatan industri yang biasanya sering menimbulkan pencemaran lingkungan, baik pembuangan limbah, pencemaran suaran maupun pencemaran udara. Sehingga kondisi kelestarian yang masih terjaga ini membuatkesehatan masyarakat setempat sangat baik. Namun di kampong ini belum 
tersedianya fasilitas kesehatan seperti Puskesmas maupun Klinik pengobatan lainnya.

\subsection{Perilaku Masyarakat}

Kampung Madong dipimpin oleh seorang Rukun Warga yang dalam menjalankan tugasnya, Rukun Warga dibantu oleh Rukun Tetangga. Mayoritas penduduk di Kampung Madong adalah beragama Islam yang bersuku Melayu. Terdapat satu buah masjid yang bernama Mesjid Hidayatul Islamiah yang terletak di tengah-tengah areal perumahan penduduk. Mesjid ini merupakan satu satunya tempat beribadah masyarakat Kampung Madong.

Beberapa budaya yang sampai kini masih ada merupakan permainan rakyat, antara lain lomba dayung sampan, pukul bantal dilaut, tangkap itik, panjat pinang dan lomba untuk anak-anak lainya. Permainan rakyat ini mereka laksanakan dalam rangka hari besar kemerdekaan Republik Indonesia. Seluruh persiapan permainan rakyat tersebut mereka lakukan dengan cara bergotong royong.

\subsection{Interaksi Sosial dan Aktivitas Perekonomian Masyarakat}

Mayoritas masyarakat di Kampung Madong Kelurahan Kampung Bugis adalah suku Melayu. Masyarakat kampung Madong sangat erat persaudaraannya, ini terlihat jika salah satu warga melaksanakan hajatan maka seluruh masyarakat setempat ikut membantu di keluarga tersebut dan ikut memeriahkan dengan menyumbang lagu dan berjoget dipanggung yang telah disediakan tuan rumah.

Masyarakat masih memegang teguh adat istiadat daerah. Sebagian besar penduduk adalah nelayan tangkap dan nelayan budidaya. Semangat kerja masyarakat untuk membudidaya ikan sangat tinggi. Semangat bergotong royong dalam hal membuat keramba jaring apung kayu yang selama ini mereka miliki dapat dilihat ketika mereka membentuk kelompok budidaya yang sudah diketahui keberadaannya oleh dinas terkait.

Pada saat ini masyarakat di Kampung Madong sudah dapat membentuk lima Kelompok Pembudidaya Ikan (Pokdakan) yang terdiri dari :

- Pokdakan Ikan Merah

- Pokdakan Berkelana

- Pokdakan Rezeki Pesisir

- Pokdakan Bawal Bintrang

- Pokdakan Maju Mandiri

Lima Pokdakan tersebut diatas dalam kehidupan sehari-hari di tengah masyarakat selalu berbagi informasi atau pengetahuan dibidangnya masingmasing seperti ilmu tentang budidaya. Kemauan masyarakat dalam mengikuti setiap pelatihan dibidang perikanan sangat besar, misalnya pelatihan untuk membesarkan jenis ikan yang berbeda dari yang mereka pelihara atau pelatihan keterampilan untuk ibu-ibu nelayan disekitarnya.

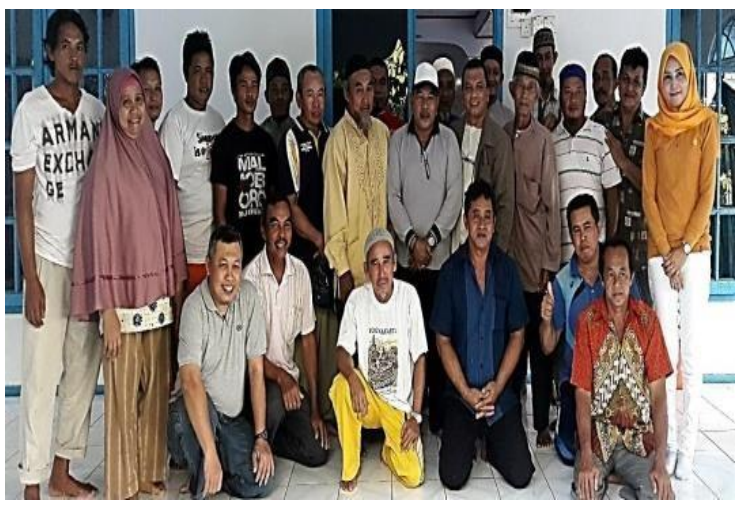

Gambar 3. Anggota KEM dan Pejabat Setempat

\subsection{Pemanfaatan Lahan Laut Secara Umum Saat ini di Desa Madong}

Sebagian besar wilayah Kampong Madong merupakan daerah pesisir, sebagian besar wilayah pesisir tersebut belum dimanfaatkan oleh masyarakat secara optimal. Wilayah ini banyak dibangun atau lebih banyak dipenuhi dengan bangunan jembatanjembatan kayu yang merupakan jalan penghubung antara satu keramba dengan keramba lainnya, sebagaimana tampak pada Gambar 4.

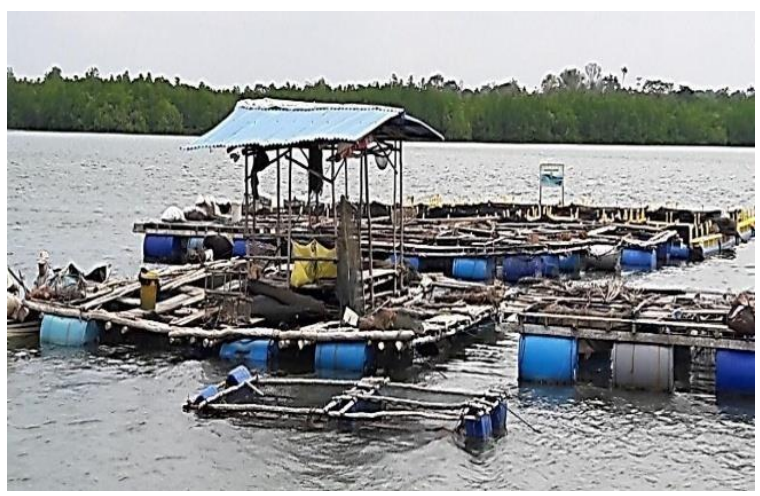

Gambar 4. Keramba Budidaya Ikan

Seluas \pm 1 ha wilayah laut sudah dimanfaatkan oleh masyarakat setempat untuk membudidaya ikan. Namun tidak tertutup kemungkinan untuk menambah keramba jaring apung tersebut berkisar $400 \mathrm{~m}^{2}$ lagi. Profesi lainnya disamping sebagai pembudidaya ikan, ada juga warga masyarakat yang berprofesi sebagai nelayan tangkap. Alat yang digunakan oleh profesi tersebut adalah jaring udang, bubu ketam dan tombak udang. Untuk menuju ke lokasi tangkap tersebut, nelayan biasanya menggunakan kendaraan laut berupa perahu berbahan kayu. Perahu yang digunakan ini sangat rentan mengalami kerusakan dengan terbatasnya umur bahan yang digunakan (kayu) sebagaimana pada Gambar 5. 


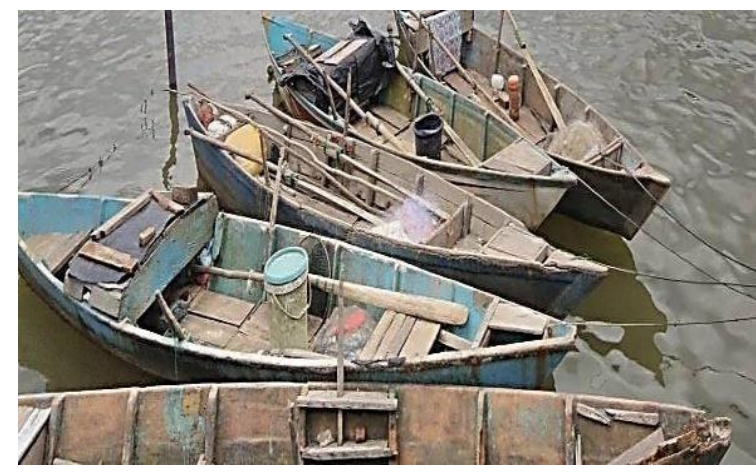

Gambar 5. Perahu nelayan milik Masyarakat Madong

\section{KAJIAN PUSTAKA}

\subsection{Budi Daya Ikan}

Menurut Rochdianto (2000), usaha ke arah pembudidayaan ikan di perairan umum kian hari memang terasa kian mendesak. Hal ini perlu dimaklumi karena jumlah permintaan ikan sebagai salah satu sumber protein hewani terus mengalami peningkatan seiring dengan bertambahnya jumlah penduduk. Selain itu, usaha penangkapan ikan yang tidak diimbangi dengan usaha budidaya dan penebaran ikan (restocking), lambat laun akan mengganggu kelestarian sumber daya perairan umum.

Meningkatnya jumlah permintaan pasar terhadap ikan segar secara tidak langsung harus dibarengi dengan peningkatan pasokan. Kondisi ini bisa iartikan bahwa peluang untuk mengembangkan usaha ikan segar masih terbuka sehingga perlu adanya budidaya ikan mas secara terus menerus (Khairuman, 2002).

Kegiatan budidaya bukan lantas memecahkan persoalan akan kebutuhan protein. Permasalahan baru yang diakibatkan oleh kegiatan budidaya ikan adalah masalah pencemaran. Pencemaran pada lingkungan perairan yang disebabkan oleh kegiatan budidaya bersumber dari buangan pakan yang tidak terkonsumsi (Dias et al, 2012), bahan sisa metabolik/feces dan urin (Erlania, 2009), serta penggunaan bahan kontruksi yang tidak ramah lingkungan.

Dalam budidaya ikan, kita bisa melakukannya dalam beberapa media, salah satunya adalah sistem Keramba Jaring Apung (KJA). Budidaya ikan keramba jaring apung bisa dilakukan baik di sungai yang dalam, danau, di atas kolam terpal, hingga laut. Budidaya ikan keramba jaring apung merupakan salah satu cara budidaya pembesaran ikan yang efisien dan efektif. Dengan luasan media yang sempit, kita bisa melipatgandakan hasil panen ikan. Pola yang dipakai adalah mengintensifkan pola budidaya ikan tersebut, yang memang akhirnya akan berdampak pada biaya tinggi namun bisa didapatkan keuntungan yang lebih tinggi pula.

\subsection{Kerambah Apung}

Perairan umum yang banyak dimanfaatkan sebagai tempat budidaya ikan adalah waduk. Waduk adalah wilayah yang digenangi badan air sepanjang tahun serta dibentuk atau dibangun atas rekayasa manusia. Waduk dibangun dengan cara membendung aliran sungai sehingga air sungai tertahan sementara dan menggenangi bagian daerah aliran sungai atau water shed yang rendah. Salah satu teknologi budidaya yang handal dalam rangka optimasi pemanfaatan perairan waduk adalah budidaya ikan dalam Keramba Jaring Apung (KJA). Selain waduk kerambah jarring apung juga bisa dilakukan di daerah pinggiran pantai dan di lautan. Kerambah jarring apung dengan pemanfaatan laut dapat membudi dayakan berbagai ikan laut seperti kerapuh dll.

Penerapan budidaya ikan air asin dalam Keramba Jaring Apung (KJA) akan memberikan keuntungan. Keuntungan tersebut yaitu berupa ongkos produksi untuk penyediaan tanah (untuk membangun kolam) berkurang, dapat mengatasi berkurangnya lahan budidaya ikan akibat terdesak oleh kegiatan pertanian, industri serta pembangunan perumahan. Secara teknis keuntungan yang diperoleh antara lain adalah intensifikasi produksi ikan dan optimasi penggunaan pakan dapat diterapkan, pesaing dan pemangsa ikan mudah dikendalikan serta pengelolaan dan pemanenan tidak terlalu rumit (Rochdianto, 2000)

\section{METODE KEGIATAN}

Pelaksanaan kegiatan KEM Madong terhitung mulai tanggal 29 September 2017. Uraian Pelaksanaan Kegiatan KEM Madong dijelaskan dalam beberapa bagian yaitu: Strategi/Metode, Indikator kinerja, dan SDM yang terlibat. Masing bagian dijelaskan pada point-point berikut:

\subsection{Strategi Pemberian Bantuan}

Strategi yang diterapkan pada KEM ini adalah pemberian bantuan kelengkapan dan bahan baku bagi masyarakat untuk meningkatkan ekonomi masyarakat. Kelengkapan dan bahan baku ini terkait dengan kegiatan harian masyarakat dalam mencari nafkah dan meningkatkan taraf hidupnya. Diharapkan keterbatasan modal masyarakat dalam menyediakan kelengkapan dan bahan baku ini dapat diatasi dengan bantuan dari Pertamina melalui program ini. Kelengkapan dan bahan baku yang diberikan diuraikan dalam sub-bab berikut:

\subsection{Bantuan Pembuatan dan Perbaikan Keramba}

Keramba adalah keranjang atau kotak dari bilah bambu untuk membudidayakan ikan, atau keramba adalah wadah budi daya ikan berupa kandang yang terbuat dari bambu atau papan kayu yang ditempatkan di air. Salah satu varian keramba yaitu keramba jaring apung yang ditempatkan di laut. Keramba jaring apung terdiri dari rangka dengan pijakan untuk inspeksi. Jaring apung menggunakan pelampung agar tetap mengapung, serta tertambat pada rangka dan jangkar sehinga tidak berpindah dari posisinya. Ikan 
tetap berada di dalam keramba karena terkurung oleh jaring.

Bentuk dari keramba yang dibangun masyarakat secara mandiri ini terbuat dari kayu yang kondisi tidak bertahan lama, sebagaimana pada Gambar 6. Bahan yang kokoh yang bertahan dalam waktu lama yaitu keramba yang terbuat dari fiberglass yang sedang berkembang baik saat ini. Harga keramba fiberglass yang relatif mahal membuat masyarakat membuat keramba sendiri dengan memanfaatkan drum bekas berbahan plastik yang dijual di pasaran. Drum-drum tersebut diikat pada kayu-kayu dan dihubungkan satu sama lain sehingga membentuk kotak/lubang yang dapat dipasang jaring. Dengan adanya drum plastik kedap udara maka keramba diharapkan tidak tenggelam sehingga mudah dikelola.

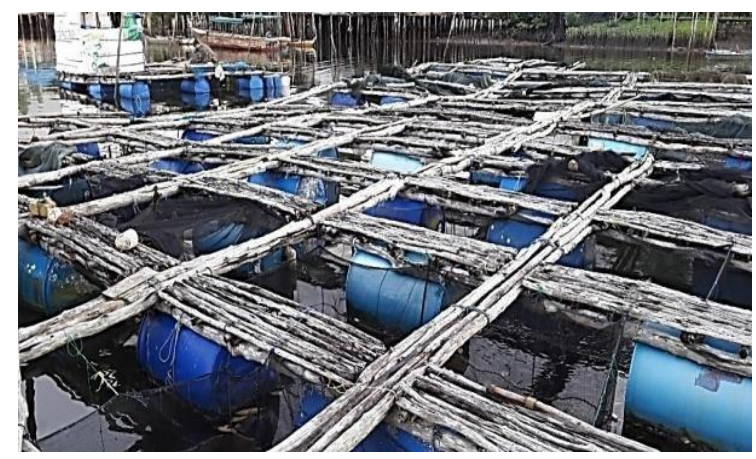

Gambar 6. Keramba Apung milik Masyarakat

Untuk membangun keramba ini bantuan yang diberikan berupa pengadaan jaring keramba, dan drum bekas kedap air. Sedangkan untuk kebutuhan kayukayu penyambung dan baut pengunci, masyarakat secara proaktif mencari kayu dari hutan terdekat dan membeli baut pengunci dengan dana pribadi/kelompok di luar bantuan KEM.

\subsection{Bantuan Bibit Ikan dan Pakan Ikan}

Dengan adanya penambahan keramba baru yang dikelola oleh masing-masing kelompok budidaya, maka masing-masing keramba akan diisi dengan bibit ikan. Beberapa kelompok akan mengembangkan ikan Kerapu Cantang dan ada kelompok lain yang akan mengembangkan bibit ikan Kakap. Mengingat kondisi cuaca di lokasi KEM yang tidak memungkinkan untuk mengembangkan bibit ikan kakap, akhirnya disepakati seluruh kelompok membudidayakan bibit ikan Kerapu Cantang. Bibit ikan yang masih kecil memerlukan pakan/makanan khusus. Pakan ikan dibagi dalam beberapa ukuran sesuai dengan ukuran ikan yang dibudidayakan. Pakan ikan bantuan dapat disimpan jika tidak diberikan ke bibit ikan yang sudah besar.

\subsection{Bantuan Jaring Tamban dan Mesin Semprot Jaring}

Pengadaan jaring tamban merupakan revisi pengadaan tipe jaring. Pada awalnya bantuan yang diberikan hanya berupa jaring keramba. Menimbang diperlukannnya keberlanjutan kegiatan, maka diperlukan jaring tamban. Jaring tamban merupakan jaring yang digunakan masyarakat nelayan untuk mencari bahan makan ikan dari laut setempat. Bahan makan ikan berupa jenis ikan lain yang dipotongpotong sebagai pakan rucah. Pakan hasil pabrikan dianggap tidak memadai diberikan jika ukuran ikan sudah besar, ukuran pakan pabrikan dianggap terlalu kecil dan akan menghambat perkembangan ukuran ikan yang dibudidayakan. Jaring tamban ini memfasilitasi masyarakan nelayan mendapatkan makanan bagi ikan di dalam keramba. Sehingga ikan di dalam keramba senantiasa mendapatkan makanan setiap hari.

Pemberian bantuan mesin semprot jaring merupakan suatu upaya agar jaring keramba tetap bersih. Kebersihan jaring keramba akan mencegah adanya penyakit bagi ikan- ikan dalam keramba. Mesin ini digunakan secara berkala untuk membersihkan jaring keramba yang kotor mengingat kondisi air laut yang tidak bersih dan merupakan aktifitas operasional budidaya ikan di keramba. Untuk bahan bakar mesin, masyarakat menyediakan sendiri dari dana pribadi/kelompok.

\subsection{Indikator Kinerja}

Pengukuran Indikator Kinerja merujuk kepada Tujuan Pelaksanaan KEM sebagaimana diuraikan pada bab sebelumnya. Uraian indikator kinerja sebagaimana dijelaskan pada sub-bab berikut ini:

- Meningkatnya ekonomi masyarakat dalam memanfaatkan hasil KEM.

- Pola KEM dapat memotivasi masyarakat wilayah sekitar dan menjadi contoh bagi masyarakat wilayah sekitar lokasi KEM.

- Dapat membantu pemerintah setempat dalam rangka percepatan peningkatan pembangunan perekonomian masyarakat.

- Meningkatnya partisipasi dosen perguruan tinggi setempat sebagai fasilisator, penguat dan pemberdaya masyarakat dalam melaksanakan pengabdian kepada masyarakat.

- Dosen/Prodikmas dapat mengembangkan ilmu pengetahuan dan upaya untuk membantu dan bersama- sama masyarakat memecahkan masalah yang dihadapi masyarakat serta peningkatan kapasitas, potensi dan kesejahteraan masyarakat.

\subsection{SDM yang terlibat}

Agar pelaksanaan KEM berjalan lancar maka masyarakat di lokasi KEM terbagi dalam beberapa kelompok yang disebut Kelompok Pembudidaya Ikan (Pokdakan).

\subsection{Strategi/Metode Pelaksanaan}

Agar pelaksanaan kegiatan KEM berjalan efektif dan efisien maka disusunlah beberapa langkah kegiatan yang mencakup; Pembentukan Kelompok Pembudidaya Ikan (Pokdakan), Survei harga seluruh 
harga barang, alat dan bahan baku sampai dengan penerimaan seluruh bantuan tersebut di lokasi KEM.

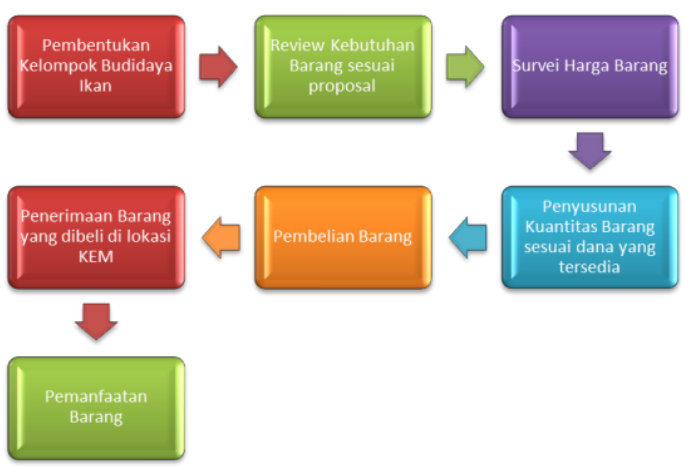

Gambar 7. Strategi Pelaksanaan KEM

\subsection{Pembentukan Kelompok Pembudidaya Ikan (Pokdakan)}

Di Desa Madung pembentukan kelompok kerja tidak mengalami kesulitan. Warga Madung tinggal merevisi anggota kelompok dari kelompok yang sudah dibentuk sebelumnya. Anggota yang tidak akftif diganti dengan anggota yang mau aktif dan mau terlibat kegiatan kegiatan KEM. Berdasarkan kesepakatan warga maka dilibatkan lima Kelompok Pembudidaya Ikan (Pokdakan), yang terdiri dari: Pokdakan Ikan Merah, Pokdakan Berkelana, Pokdakan Rezeki Pesisir, Pokdakan Bawal Bintrang dan Pokdakan Maju Mandiri. Nama-nama anggota kelompok sebagaimana pada tabel dibawah ini:

Tabel 1. Daftar Nama Kelompok Pembudidaya Ikan

\begin{tabular}{|c|l|l|l|l|l|}
\hline No & $\begin{array}{l}\text { POKDA } \\
\text { KAN } \\
\text { BERKE } \\
\text { LANA }\end{array}$ & $\begin{array}{l}\text { POKDAK } \\
\text { AN IKAN } \\
\text { MERAH }\end{array}$ & $\begin{array}{l}\text { POKDAK } \\
\text { REZEKI } \\
\text { PESISIR }\end{array}$ & $\begin{array}{l}\text { KOKDA } \\
\text { MAJU } \\
\text { MANDIR }\end{array}$ & $\begin{array}{l}\text { POKDAKA } \\
\text { N BAWAL } \\
\text { BINTANG }\end{array}$ \\
\hline 1 & Alias & Aris & M. Aris & Amzah & Nazaruddin \\
\hline 2 & $\begin{array}{l}\text { Muham } \\
\text { mad }\end{array}$ & Roslan & $\begin{array}{l}\text { Syahren } \\
\text { M. }\end{array}$ & Endra & Rizal \\
\hline 3 & Romlah & Mustakim & Arif & Iman & Asnah \\
\hline 4 & $\begin{array}{l}\text { Ali } \\
\text { Malek }\end{array}$ & Haidir & M. Ali & Kalil & Junaidi \\
\hline 5 & $\begin{array}{l}\text { A Rahim } \\
6\end{array}$ & Amir & M. Amin & Saleh & $\begin{array}{l}\text { Rusadi } \\
\text { Rahmat }\end{array}$ \\
\hline 7 & Makrup & Ahmad & Mat takoi & Atan & Azli \\
\hline 8 & $\begin{array}{l}\text { Aminud } \\
\text { in Amin }\end{array}$ & Ibrahim & Ahmad & Azhar & M. Ricky \\
\hline 9 & Idin & Yusup & Alyas & Amat & \\
\hline 10 & M. Nur & Zainal & Zamri & Nizal & \\
\hline 11 & Zulkifli & M. Adam & & & \\
\hline 12 & Nasir & & & & \\
\hline
\end{tabular}

Untuk manajemen pelaksanaan KEM maka, pengelola Flipmas Wilayah Batobo menyusun jalur komandio dan koordinasi sebagaimana pada Gambar di bawah ini.

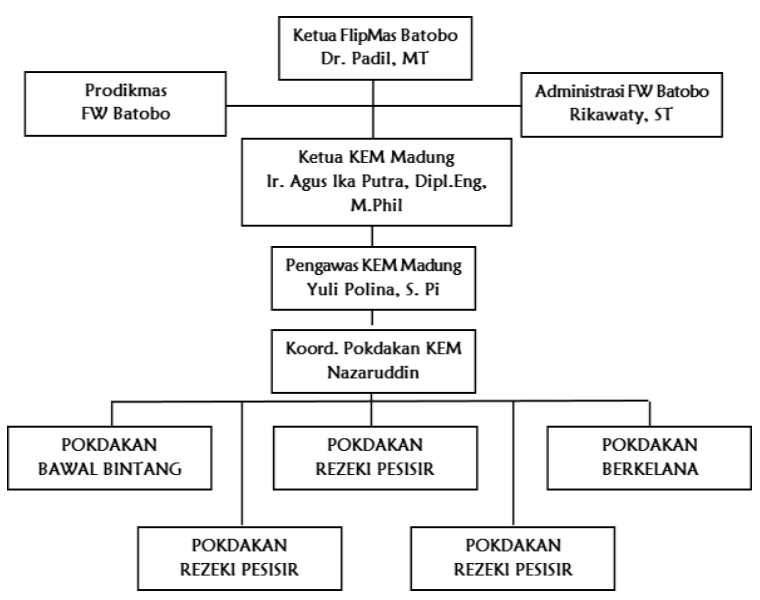

Gambar 8. Struktur Organisasi KEM MadungKEPRI.

\subsection{Review Kebutuhan Item}

Penyesuai kuantitas dan jenis barang juga perlu dilakukan untuk mengakomodir besanya dana pada tahap pertama, yaitu sebesar $70 \%$ dari total dana bantuan. Berdasarkan diskusi dengan seluruh kelompok maka dilakukan penyesuaian spesifikasi dan kuantitas barang yang akan dibeli. Misalnya sebagian jenis jaring keramba dialihkan ke jenis jaring Tamban. Jaring Tambandigunakan untuk pemenuhan kebutuhan pakan ikan jika ukuran bibit ikan di keramba sudah membesar.

\subsection{Survei Harga}

Survei harga dilakukan bertujuan mendapatkan harga dipasaran pada saat ini. Perbedaan harga pasaran dengan besaran harga di proposal KEM besar kemungkinan terjadi, mengingat adanya fluktuasi harga barang selama lebih kurang tujuh bulan mulai dari pengajuan proposal sampai diterimanya dana KEM. Penyesuaian harga, akan ada tindakan penyesuaikan spesifikasi dan kuantitas barang yang akan dibeli. Untuk penyesuaian harga satuan dan kuantitas maka dilakukan revisi distribusi barang dan bahan.

Survei harga dilakukan Pengawas KEM bersama perwakilan Pokdakan ke beberapa toko dan suplier. Barang-barang berupa drum, jaring, tali, bibit ikan, pakan ikan dan mesin semprot diperoleh secara lengkap daftar harganya serta spesifikasinya. Hargaharga tersebut menjadi bahan perbandingan untuk memilih tempat/toko/supplier tempat belanja.

\subsection{Sistem Pengadaan Barang}

Sebelum pengadaan barang dilaksanakan, perwakilan Pokdakan. Pengawas KEM dan Ketua KEM melakukan musyawarah untuk memutuskan barang yang mana yang akan dibeli dan dimana akan dibeli. Setelah diputuskan maka dilanjutkan dengan perhitungan kembali dana yang tersedia berdasarkan harga satuan dan jumlah/kuantitas barang yang akan 
dibeli. Pembelian barang disesuaikan dengan kuantitas barang yang dibeli pada tahap pertama yaitu pencairan dana 70\% sebesar Rp. 210.000.000 dan pencairan dana Tahap kedua sebesar $30 \%$ dengan nilai $\mathrm{Rp}$. 90.000.000,-

Pengadaan barang dan bahan bantuan dilakukan dengan cara belanja langsung ke toko/supplier yang menjual barang tersebut. Berdasarkan kesepakatan pengelola KEM dengan masyarakat penerima bantuan, maka Pengawas, Ketua KEM dan perwakilan Pokdakan membeli langsung barang-barang. Pembayaran ke toko/supplier dilakukan dengan cara transfer antar bank, dari rekening FW ke rekening Ketua KEM dalam dua tahap dan kemudian didistribusikan ke rekening toko, juga melalui transfer antar bank. Pembayaran dilakukan secara penuh atau bertahap dengan uang muka untuk barang yang belum ada di tempat sehingga harus di pesan terlebih dahulu. Bukti untuk setiap pembayaran diarsipkan dan dilaporkan ke pengurus Flipmas. Salinan Bukti pembayaran juga di serahkan ke Pokdakan agar masyarakat juga bisa mengontrol pengeluaran dana.

\subsection{Sistem Penerimaan Barang/Bahan}

Penerimaan barang dilakukan langsung oleh masyarakat (Pokdakan) ketika barang sampai di lokasi KEM. Anggota Pokdakan langsung memeriksa kondisi barang (Termasuk bibit ikan) dan jumlah/kuantitas barang yang dibeli. Misalnya bibit ikan yang datang ke lokasi KEM, langsung diukur besarnya dan dihitung jumlahnya satu persatu kemudian baru dimasukkan ke keramba yang sudah disiapkan. Kondisi bibit itu juga diperiksa harus dalam keadaan sehat. Untuk setiap barang/bahan yang diterima oleh perwakilan Pokdkan maka pengelola KEM (Flipmas) dilengkapi dengan surat Berita Acara Serah Terima (BAST) barang yang ditandatangani oleh perwakilan/ketua Pokdakan. Distribusi barang/bahan disesuaikan dengan isian proposal awal.

\subsection{Pemanfaatan Barang/Bahan}

Pemanfaatan barang yang sudah diterima selanjutnya diolah lagi oleh masing-masing kelompok. Pada saat ini seluruh barang dan bahan yang diterima masyarakat dengan dana Tahap 1 sudah dimanfaatkan secara optimal.

Seluruh drum sudah digunakan seluruh kelompok untuk kerambanya. Ada kelompok yang membuat keramba baru dan ada kelompok yang melengkapi kekurangan drum pada keramba yang sudah ada sebelumnya. Jaring keramba yang diterima diolah masyarakat secara mandiri berdasarkan keterampilan warga dalam menjahit dan membentuk jaring keramba. Ukuran jaring disesuaikan dengan ukuran bibit ikan yang ditempatkan. Mesin semprot jaring juga sudah mulai digunakan warga untuk membersihkan jaring keramba yang kotor. Benih Ikan Kerapu sesuai hasil revisi sudah diterima oleh warga dengan total 10.100 ekor. Pakan ikan disesuaikan spesifikasinya dengan ukuran ikan. Tiap kelompok juga menghitung jumlah pakan yang digunakan tiap harinya, catatan penggunaan pakan diarsipkan di tiap kelompok.

Pakan ikan yang dibeli pada tahap 1 diperkirakan akan habis dalam waktu 2,5 bulan. Untuk itu diharapkan realisasi dana $30 \%$ dapat dilaksanakan sesegera mungkin. Kebutuhan jaring tamban juga sangat mendesak, karena ukuran benih ikan yang sudah membesar memerlukan pakan rucah yang diperoleh dengan menggunakan jaring tamban. Persiapan Jaring Tamban (memotong- merakit) memakan waktu lebih kurang 2 minggu untuk bisa digunakan.

\subsection{Pembagian Tugas Anggota}

Dengan adanya keramba baru dan perbaikan keramba lama, maka agar pengelolaannya lebih optilmal, pengelolaan keramba diatur dengan penugasan secara bergilir kepada seluruh anggota kelompok pembudidaya. Selain anggota kelompok dapat berbagi tugas, juga dapat saling belajar bagaimana mengelola keramba dengan baik. Pencatatan anggota yang bertugas memberi makan dilakukan oleh ketua kelompok. Tiap hari minggu disepakati untuk dilakukan kegiatan bersama gotong-royong membersihkan/pemeliharaan keramba.

\section{HASIL DAN PEMBAHASAN}

Perhitungan kemajuan pekerjaan dibagi dalam dua kategori, kategori 1 yaitu kemajuan pekerjaan terhadap dana tahap 1 (70\%) dan kategori 2 yaitu kemajuan pekerjaan terhadap seluruh dana (tahap1 dan tahap2).

\subsection{Penyerapan Dana Bantuan}

Penyerapan dana bantuan dibagi dalam dua tahap sesuai tahap pencairan dana. Tahap 1, pencairan dana sebesar $70 \%$ dan Tahap2, sebesar $30 \%$. Rincian penyerapan dana sebagaimana tampak pada Tabel 5.

\subsection{Tahapan Pelaksanaan Kegiatan}

Tahapan pelaksanaan kegiatan berupa sebagaimana tampak pada skema alur kegiatan sebagai berikut:

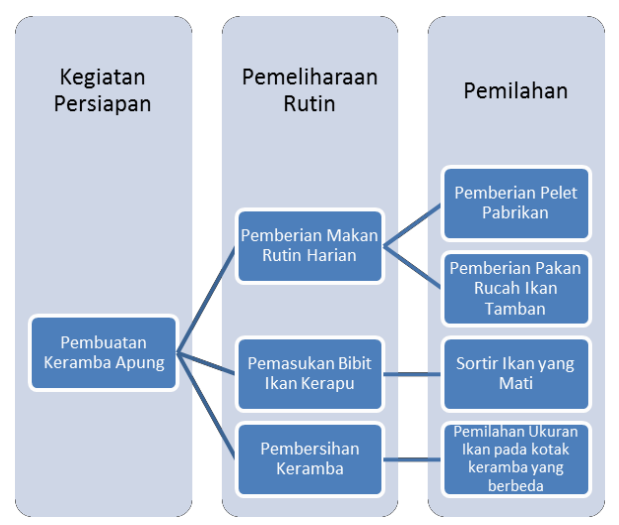

Gambar 9. Tahapan Pelaksanaan KEM

Pembuatan Keramba Apung dilakukan dengan menggunakan drum bekas yang dibeli dari dana 
bantuan. Untuk menghubungkan drum-drum tersebut masyarakat menggunakan kayu yang diusahakan sendiri oleh masyarakat dengan mencari kayu di hutan yang berada pada pulau-pulau sekitar. Alat Bantu yang digunakan berupa Gergaji pemotong kayu, Bor Kayu dan alat lainnya

\subsection{Hambatan dan Langkah Penyelesaian}

Hambatan yang paling mendasar adalah adanya gangguan penyakit pada bibit ikan di keramba dan saling memangsa antar bibit ikan. Gangguan penyakit ini bisa disebabkan oleh tercemarnya air laut oleh kondisi cuaca dan arus air didasar laut. Hal ini dirasakan setelah adanya cuaca yang tidak kondusif di lokasi keramba. Berdasarkan Laporan Hasil Uji yang dilaksanakan oleh Laboratorium Penguji Stasiun Karantina Ikan Pengendalian Mutu dan Keamananan Hasil Perikanan Kelas II Tanjung Pinang, bahwa bibit ikan Kerapu positif terkena virus jenis Virus RSIVD.

Langkah-langkah penyelesaian adalah upaya pencegahan dan pengobatan. Pencegahan dilakukan dengan memisahkan ikan yang terkena penyakit dan mencuci ikan dengan air tawar secara rutin. Ikan-ikan yang sakit diobati secara tradisional yaitu dengan bahan alami berupa daun sungai laut dan kunyit. Kemudian karena pekembangan ukuran ikan tidak merata, maka dilakukan upaya memisahkan ikan ukuran besar dengan ukuran kecil agar tidak saling memangsa dalam kotak keramba yang terpisah. Langkah-langkah tersebut merupakan pengalaman dari Nelayan setempat yang menurut mereka cukup efektif mengurangi kematian bibit ikan.

\subsection{Pencapaian Program}

Dengan adanya program ini,jumlah penerima manfaat sebanyak 51 orang yang terbagi dalam lima kelompok kecil untuk memudahkan pelaksanaan kegiatan. Sampai dengan laporan ini disampaikan \pm 8 bulan, kegiatan panen baru saja dilaksanakan. Mengingat budidaya ikan jenis kerapu cantang memerlukan waktu sampai dengan 8 bulan dengan berat ikan 700800 gram/ekor. Dikarenakan proses panen dilakukan sacara bertahap,maka berikut kami sampaikan perkembangan ikan sampai dengan kondisi fisik layak jual. Berikut adalah grafik perkembangan ikan.
Tabel 2. Perkembangan fisik ikan Kelompok Maju Mandiri

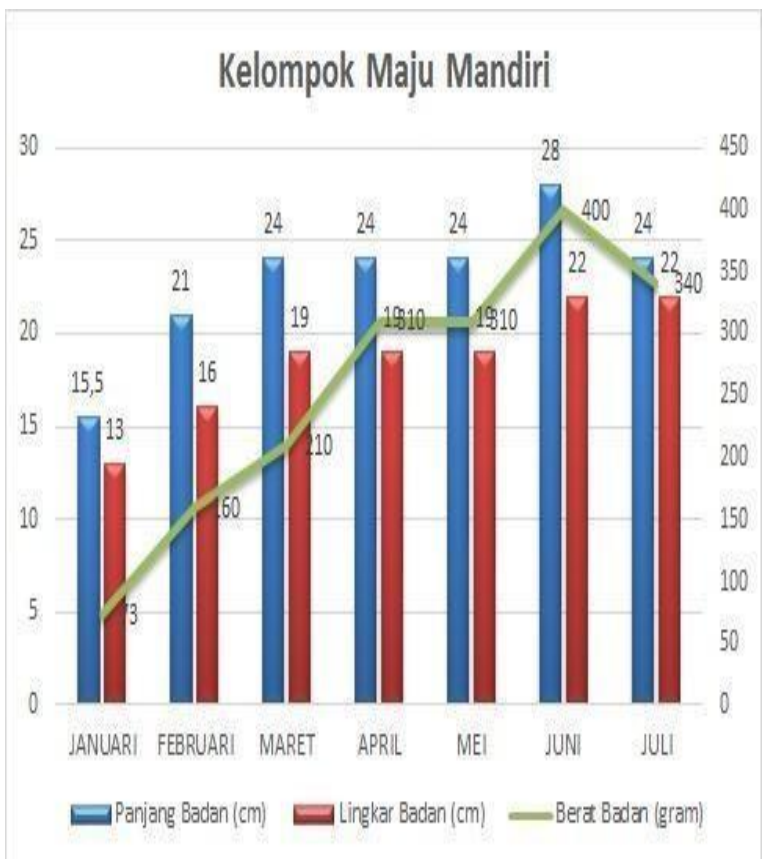

Tabel 3. Perkembangan fisik ikan kelompok Bawal Bintang

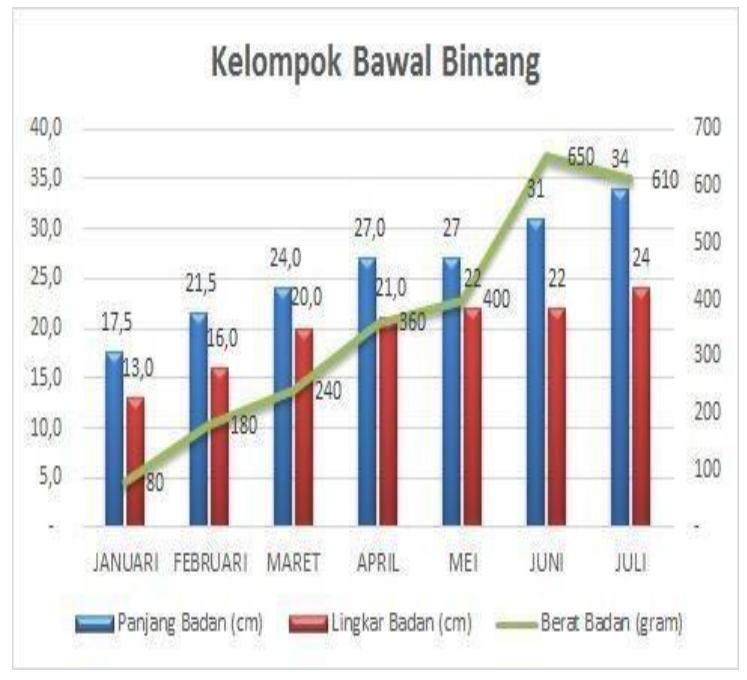


Tabel 4. Perkembangan fisik ikan kelompok Ikan Merah

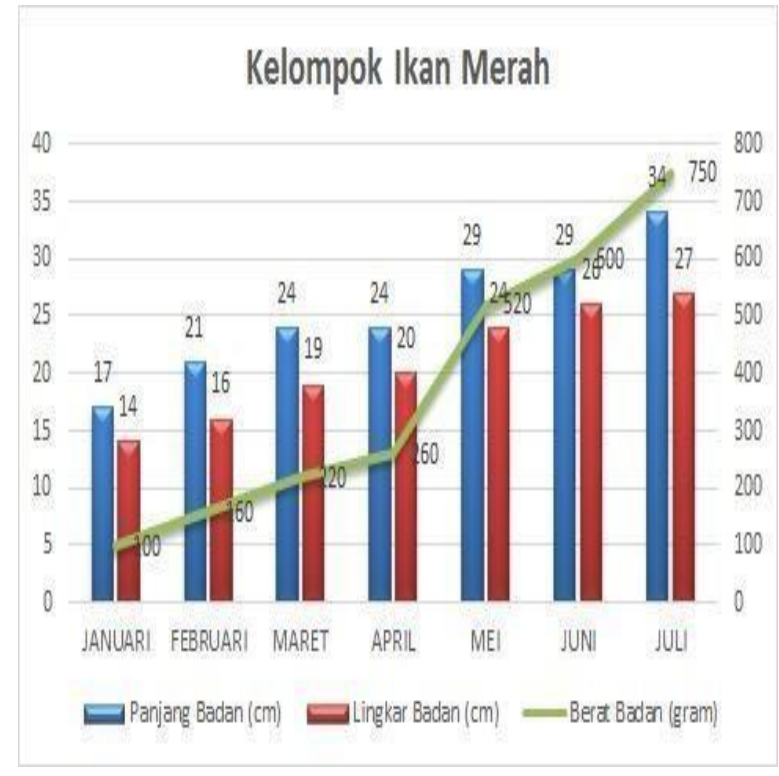

Tabel 5. Perkembangan Fisik ikan kelompok Berkelana

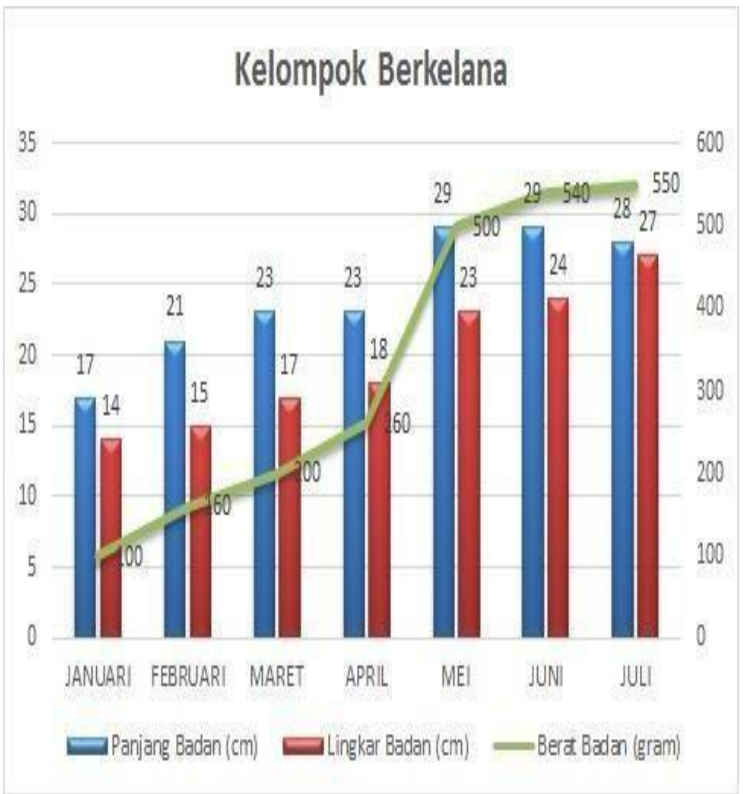

Tabel 6 Perkembangan fisik ikan kelompok Rezeki Pesisir

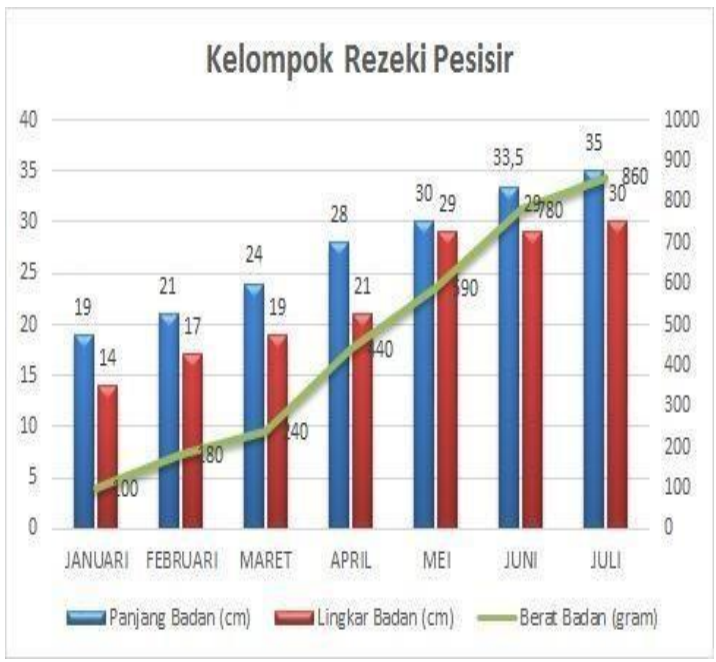

Berdasarkan tabel diatas, terdapat fluktuasi penurunan, hal ini dikarenakn pengukuran ikan tidak dilakukan terhadap ikan yang sama namun pada keramba yang sama. lah Dikarenakan masih tahap panen sampai dengan agustus 2018, maka berikut adalah perkiraan hasil panen.

Tabel 7. Perkiraan kasar hasil panen Ikan Kerapu Cantang bulan uli

Perkiraan Panen Ikan Kerapu Cantang - KEM Madung Kepri

\begin{tabular}{l|l|r|r|r|r|r|r|}
\hline No & Nama Kelompok & $\begin{array}{c}\text { Jumlah } \\
\text { Ikan }\end{array}$ & $\begin{array}{c}\text { Perkiraan } \\
\text { Berat } \\
\text { Ikan }\end{array}$ & $\begin{array}{c}\text { Total Berat } \\
\text { (gram) }\end{array}$ & kg & Harga per kg & Total (Rp) \\
\hline 1 & Bawal Bintang & 600 & 700 & 420.000 & 420 & 110.000 & 46.200 .000 \\
\hline 2 & Berkelana & 160 & 650 & 104.000 & 104 & 110.000 & 11.440 .000 \\
\hline 3 & Rezeki Pesisir & 400 & 750 & 300.000 & 300 & 110.000 & 33.000 .000 \\
\hline 4 & Maju Mandiri & 140 & 550 & 77.000 & \multicolumn{1}{c|}{77} & 110.000 & 8.470 .000 \\
\hline 5 & Ikan Merah & 205 & 650 & 133.250 & 133,25 & 110.000 & 14.657 .500 \\
\hline & & & & $1.034,250$ & 1034,25 & & 113.767 .500 \\
\hline & & & & 1.034 & & & \\
\hline
\end{tabular}

\subsection{Pembahasan}

Berdasarkan paparan dan tabel di atas terlihat gambaran perkembangan fisik ikan yang meningkat dari bulan ke bulan setelah dilakukan kegiatan budi daya melalui jarring apung dengan memanfaatkan lingkungan sekitar. Perkembangan tersebut dapat dilihat dari panjang badan dan lingkar badan ikan yang dipelihara denga menggunakan system jarring apung yang dikembangkan warga.

Lima kelompok yang menjadi sasaran KEM merasakan manfaat budi daya jarring apung dapat meningkatkan perkembangan ikan dengan cepat sehingga dapat membantu meningkatkan produksi pangan yang sangat dibutuhkan oleh warga masyarakat sekitar pesisir pantai. 


\section{KESIMPULAN DAN SARAN}

\subsection{Kesimpulan}

a) Pembangunan Kawasan Ekonomi Masyarakat (KEM) berbasis pada perikanan terutama budidaya yang memanfaatkan laut, terbukti dapat membuka pola pikir dan wawasan masyarakat dalam upaya memenuhi kebutuhan hidup khususnya bagi warga masyarakat sekitar pesisir pantai.

b) Perkembangan budidaya ikan dengan memanfaatkan kerambah apung terbukti dapat mempercepat proses perkembangan ikan dan mempermudah masyarakat dalam merawat dan melakukan pemanenan dengan waktu delapan bulan.

\subsection{Saran}

a) Pembangunan Kawasan Ekonomi Masyarakat (KEM) berbasis pada perikanan terutama budidaya yang memanfaatkan laut, harus memperhatikan kondisi musim/cuaca pada saat memasukan bibit ikan. Hal ini untuk menghindari tingginya tingkat kematian pada bibit ikan pada fase beradaptasi dengan lingkungan baru.

b) Selain itu, sambil menunggu dan merawat ikan hingga massa panen kurang lebih 8 bulan kedepan, sebaiknya warga KEM juga mencoba bertani agara adanya pemasukan harian.

\section{DAFTAR PUSTAKA}

Dias, M. O., Junqueira, T. L., Cavalett, O., Cunha, M. P., Jesus, C. D., Rossell, C. E., ... \& Bonomi, A. (2012)

Integrated versus stand-alone second generation ethanol production from sugarcane bagasse and trash. Bioresource

technology, 103(1), 152-161.

Erlania, E. (2009). PROSPEK PEMANFAATAN MIKROALGA SEBAGAI SUMBER PANGAN ALTERNATIF DAN BAHAN FORTIFIKASI PANGAN. Media Akuakultur, 4(1), 59-66.

Khairuman, A., \& Khairul, A. (2002). Membuat pakan ikan konsumsi. Agromedia Pustaka. Jakarta.

Susanto, H., \& Rochdianto, A. (2000). Kiat budi daya ikan mas dilahan kritis. Penebar Swadaya. 